\title{
Altered Oligodendrocytes in Spinal Enlargements of Streptozotocin Diabetic Rats
}

\author{
Oligodendrocitos Alterados en la Intumescencia Espinal de Ratas Diabéticas con Estreptozotocina
}

Sani Baimai; Sirorat Janta; Passara Lanlua; Amornrat Chookliang; Apichaya Niyomchan \& Sirinush Sricharoenvej

BAIMAI, SANI; JANTA, S.; LANLUA, P.; CHOOKLIANG, A.; NIYOMCHAN, A.; SRICHAROENVEJ, S. Altered oligodendrocytes in spinal enlargements of streptozotocin diabetic rats. Int. J. Morphol., 38(6):1606-1613, 2020.

SUMMARY: Disturbances of sensory and motor nerve conduction velocity in the spinal cord as well as degenerated myelin sheaths are observed in diabetic patients and animal models. Indeed, oligodendrocytes (OLs), which are important neuroglial cells, generate myelin in the central nervous system. Spinal enlargement, including cervical and lumbar enlargements, innervates all limbs. Thus, the purposes of this study were to examine and compare the ultrastructural alterations of OLs in spinal enlargements of streptozotocin (STZ)induced diabetic rats and controls. Thirteen male Sprague-Dawley rats were induced with STZ in citrate buffer and six control rats were injected with the same buffer solution. All rats were sacrificed after inductions at four (short-term DM) and twenty-four weeks (long-term DM). The selected spinal enlargements were processed for transmission electron microscopy. The OL alterations in both the cervical and lumbar enlargements were apparently the same. In short-term DM, the nuclei of OLs became swelled with chromatin clumping. Cytoplasmic organelles were moderately damaged. In long-term DM, OLs contained shrinkage nuclei with thick heterochromatin clumping. Severely degenerated mitochondria with disrupted cristae and broken membranes were observed. Moreover, distended and fragmented rough endoplasmic reticulum were observed, and large clear areas were present in the cytoplasm. Additionally, the loosening, splitting, and destruction of myelin lamellae were found. This study can provide important preliminary information about the alteration of OLs in the spinal cords of diabetic patients, which might be involve in the impairments of sensory and motor conduction velocities in these individuals.

KEY WORDS: Spinal enlargement; Oligodendrocyte; Myelin; Diabetes mellitus; Streptozotocin.

\section{INTRODUCTION}

Diabetes mellitus (DM) is characterized by chronic hyperglycemia resulting from defects in insulin secretion, insulin action, or both (Fauci et al., 2009). DM-related complication in some areas of the central nervous system (Niyomchan et al., 2019), such as the spinal cord (Sricharoenvej et al., 2015; Lanlua et al., 2019), have been reported. The spinal cord is related to integrating and modulating both sensory input from the peripheral nerves to the higher center and output from the higher center to the peripheral organs (Fitzgerald et al., 2011). It has been shown that the sensory and motor nerve conductions in both ascending and descending tracts of the spinal cords of diabetes are slower than those in controls (Gregersen, 1967; Terada et al., 1993). In diabetic patients, DM can cause abnormalities in nerve conduction velocity, such as increasing mean latency and decreasing amplitude and velocity values in the median nerve, sural nerve, and nerves that supply knee and ankle joints (Yadav et al., 2015; Tehrani, 2018). The nerve conduction velocity mainly reflects myelin changes (Yadav et al.;
Tehrani). In the mammalian nervous system, oligodendrocytes (OLs) are known to function as myelin producers of axons in the CNS. Importantly, myelination is essential for the normal function of the mature spinal cord to promote the rapid and efficient conduction of electrical impulses (Simons \& Nave, 2016). The upper and lower limbs are innervated by neurons of cervical and lumbar enlargements of the spinal cord (Fitzgerald et al.). Moreover, the morphology of both white and gray matters is altered in DM in the form of swollen axons, demyelination, and degeneration of nerve fibers (Williamson, 1904; Olsson et al., 1968).

However, the data concerning ultrastructural changes of the OLs are unclear regarding spinal cord enlargements in diabetes. Thus, the aim of this study was to demonstrate and compare the ultrastructural alterations of OLs in the cervical and lumbar enlargements of the spinal cord in short- and long-term streptozotocin (STZ)-induced diabetic rats by using transmission electron microscopy (TEM). 


\section{MATERIAL AND METHOD}

Experimental animals and diabetic induction. Nineteen male Sprague-Dawley rats (National Laboratory Animal Center, Mahidol University, Thailand) aged 5-8 weeks and weighing 200-270 g were used. All animal procedures were performed according to the Guide for the Care and Use of Laboratory Animals and approved by the ethics committee of Siriraj Laboratory Animal Research and Care Center, Mahidol University (COA No. 014/2555). After acclimatization, rats were fasted for at least $6 \mathrm{~h}$, and the glucose concentration in urine was determined by using urinalysis control strips (Diabur Test 5000, Roche Ltd., Mannheim, Germany). A blood sample obtained from a tail vein was measured by using the blood glucose monitoring system (OneTouch ${ }^{\circledR}$ Ultra ${ }^{\circledR}$, California, USA). If the results of the urine glucose and the whole blood glucose levels were $0 \mathrm{mg} / \mathrm{dL}$ and below $300 \mathrm{mg} / \mathrm{dL}$, respectively, the rats could be used in the experiment. The rats were randomly divided into two main groups: STZ-induced diabetes (short-term = 6 , long-term $=7$ ) and control (short-term $=3$, long-term $=$ 3 ) groups. In the diabetic group, each rat was injected intraperitoneally with a single dose of $60 \mathrm{mg} / \mathrm{kg}$ body weight of STZ in citrate buffer. Control rats were injected intraperitoneally with the same buffer. All rats were sacrificed at the 4th (short-term) and 24th week (long-term) after the inductions.

Ultrastructural study of oligodendrocytes in spinal enlargements. Each rat was anesthetized by halothane inhalation and perfused with $0.1 \mathrm{M}$ phosphate buffer solution (PBS), followed by injection of $2.5 \%$ glutaraldehyde in 0.1 M PBS. Then, the spinal cords in both groups were removed, dissected at the levels of cervical and lumbar enlargements, cut into small pieces approximately $1 \times 1 \times 1$ $\mathrm{mm} 3$, postfixed in $1 \%$ osmium tetroxide in $0.1 \mathrm{M}$ PBS, dehydrated in a graded series of ethanol, cleared in propylene oxide, infiltrated by propylene oxide, and embedded in plastic. The specimens were serially sectioned at a thickness of 80-85 $\mathrm{nm}$ by an ultramicrotome (Leica EM UC6, Vienna, Austria) and stained with uranyl acetate and lead citrate. The ultrastructural changes of OLs in both spinal enlargements were observed and photographed under TEM (JEOL JEM 100S, Tokyo, Japan).

Statistical analysis. The data are expressed as the mean \pm standard deviation (SD). The body weights were compared between control and diabetic rats. Differences between groups were analyzed by using the Mann-Whitney U test (SPSS version 18.0 software, Inc., Chicago, IL, USA). Differences were considered to be significant at a p-value $<$ 0.05 .

\section{RESULTS}

The diabetic rats displayed the characteristic signs of diabetes such as increased food and water consumption. However, the body weights of diabetic rats were significantly lower than those of the control rats (Table I). All diabetic rats were hyperglycemic, as shown in Table I. The urine glucose levels of DM and control rats were greater than 500 $\mathrm{mg} / \mathrm{dL}$ and $0 \mathrm{mg} / \mathrm{dL}$, respectively. Under TEM observation, in the control of both short- and long-term of cervical and lumbar enlargements, OLs exhibited similar ultrastructural appearances. The nucleus of OL was a round or oval shape with nuclear chromatin clumping beneath the nuclear envelope. The OLs were rich in cell organelles, including rough endoplasmic reticulum (rER), Golgi apparatus, mitochondria, ribosomes, and microtubules. A single cistern of rER with ribosomes was common. Ribosomes were found on the outer nuclear membrane and relatively large numbers of polysomes were observed in the cytoplasm. The Golgi apparatus was well-developed with both cisternae and vesicles throughout the perikaryal cytoplasm. The mitochondrial cristae and its membrane were observed. The microtubules were found in parallel arrays throughout the cell processes of OLs (Figs. 1A,C, 2A,C, 3A,C, 4A,C).

In short- and long-term DM, there were numerous significant signs of degeneration and ultrastructural changes of OLs in the cervical and lumbar enlargements. However, the severity of OL alterations in long-term DM was more deteriorative than that in short-term DM. In short-term DM, the nuclear membranes of OLs swelled with slightly condensed heterochromatin beneath the nuclear membrane. Cytoplasmic organelle injuries, such as swollen and vacuolated mitochondria with ruptured cristae, distension of rER, disintegration of polysomes, and dilated Golgi apparatus, were observed (Figs. 1B,D, 2B,D).

In the long-term DM, more destroyed OLs were clearly seen. The nucleus of OL contained increased heterochromatin clumping both beneath the inner nuclear membrane and in the nucleoplasm. Moreover, there was severe degeneration of cytoplasmic organelles. Mitochondria appeared to decrease in size with disruption of mitochondrial cristae and broken mitochondrial membranes. The fragmentation of rER, as well as a large clear area, was observed in the cytoplasm. In addition, remnants of other cytoplasmic organelles, which could be described as unidentified dense particles, were present in the cytoplasm (Figs. 3B,D, 4B,D).

In the cross-section of the axon, the normal axon was surrounded by compact layers of the myelin sheath (Figs. 
Table I. Comparisons in the body weights and the whole blood glucose levels of the short- and long-term diabetic and control rats.

\begin{tabular}{llcc}
\hline Groups & & Body weights $(\mathrm{g})$ & $\begin{array}{c}\text { Whole blood glucose } \\
\text { levels }(\mathrm{mg} / \mathrm{dL})\end{array}$ \\
\hline $\begin{array}{l}\text { Short term } \\
\text { Control }\end{array}$ & $(\mathrm{n}=3)$ & $327.17 \pm 11.79$ & $111.83 \pm 16.32$ \\
$\begin{array}{l}\text { Diabetes } \\
\text { Long term }\end{array}$ & & $270.88 \pm 16.19^{*}$ & $487.65 \pm 18.56^{\mathrm{a}}$ \\
Control & $(\mathrm{n}=3)$ & $456.22 \pm 8.05$ & $122.00 \pm 11.19$ \\
Diabetes & $(\mathrm{n}=7)$ & $394.63 \pm 8.35^{*}$ & $451.62 \pm 22.72^{\mathrm{a}}$ \\
\hline
\end{tabular}

The data were expressed as a mean $\pm \mathrm{SD}$. *p-value $<0.05$ compared to the control rats. a;

The blood glucose levels were more than $300 \mathrm{mg} / \mathrm{dL}$, rats became diabetes.
5A,C). In short-term DM, loosening and splitting of myelin sheaths were demonstrated (Fig. 5B). In long-term DM, the severe destruction intensive splitting and loosening of the myelin lamellae were observed (Fig. 5D).

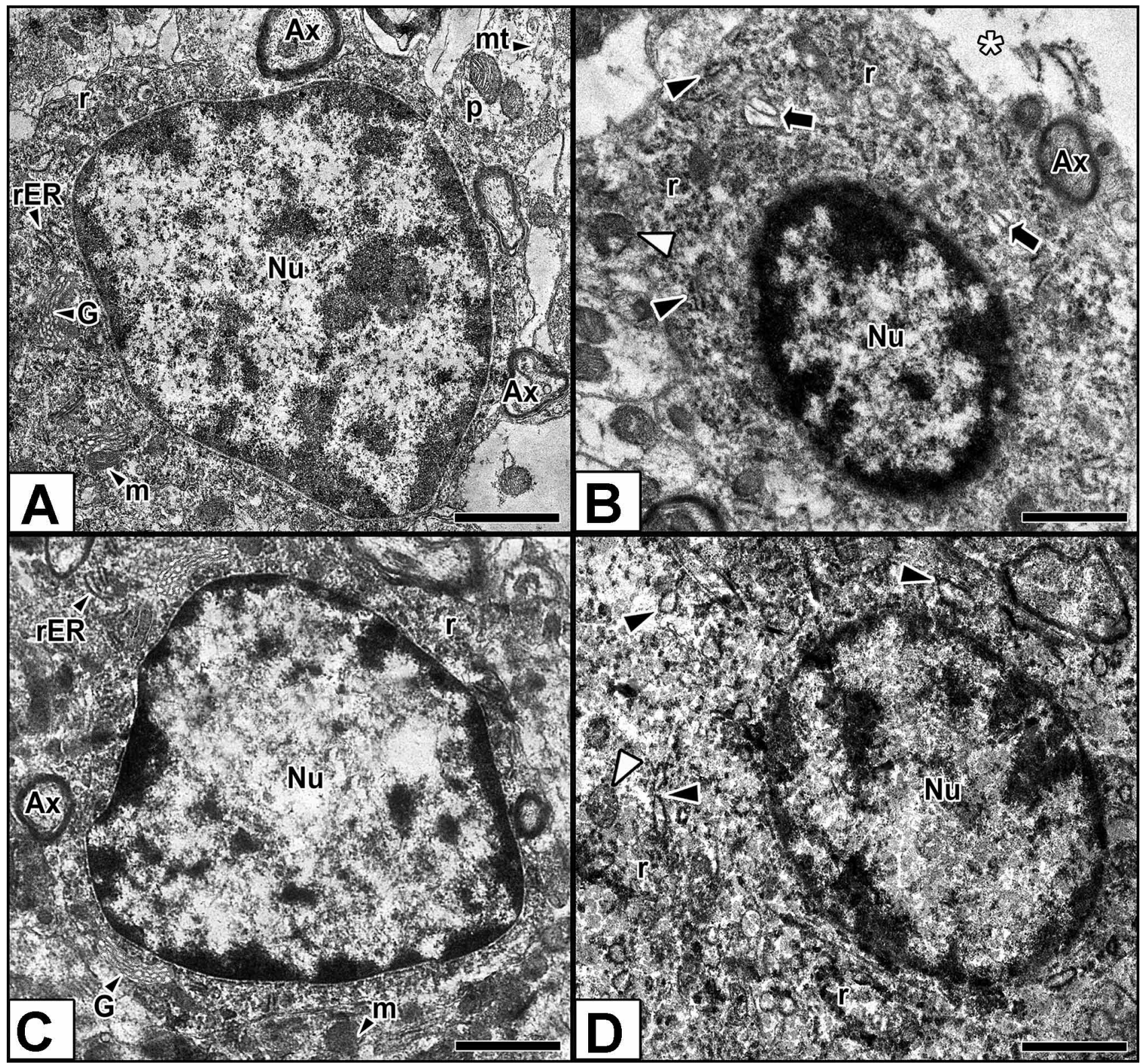

Fig. 1. Transmission electron micrographs of OLs in the cervical (1A-B) and lumbar (1C-D) enlargements of short-term control (1A, 1C) and short-term diabetic (1B, 1D) rats. Nucleus $(\mathrm{Nu})$; axon $(\mathrm{Ax})$; an oligodendroglial process (p); Golgi apparatus $(\mathrm{G})$; polysomes (r); mitochondria (m); microtubule (mt); rough endoplasmic reticulum (rER); swollen mitochondria (white arrowheads); distension of rER (black arrowheads); dilated Golgi apparatus (black arrows); electron lucent ectoplasmic area (a white asterisk). Scale bar $=2 \mu \mathrm{m}$ 


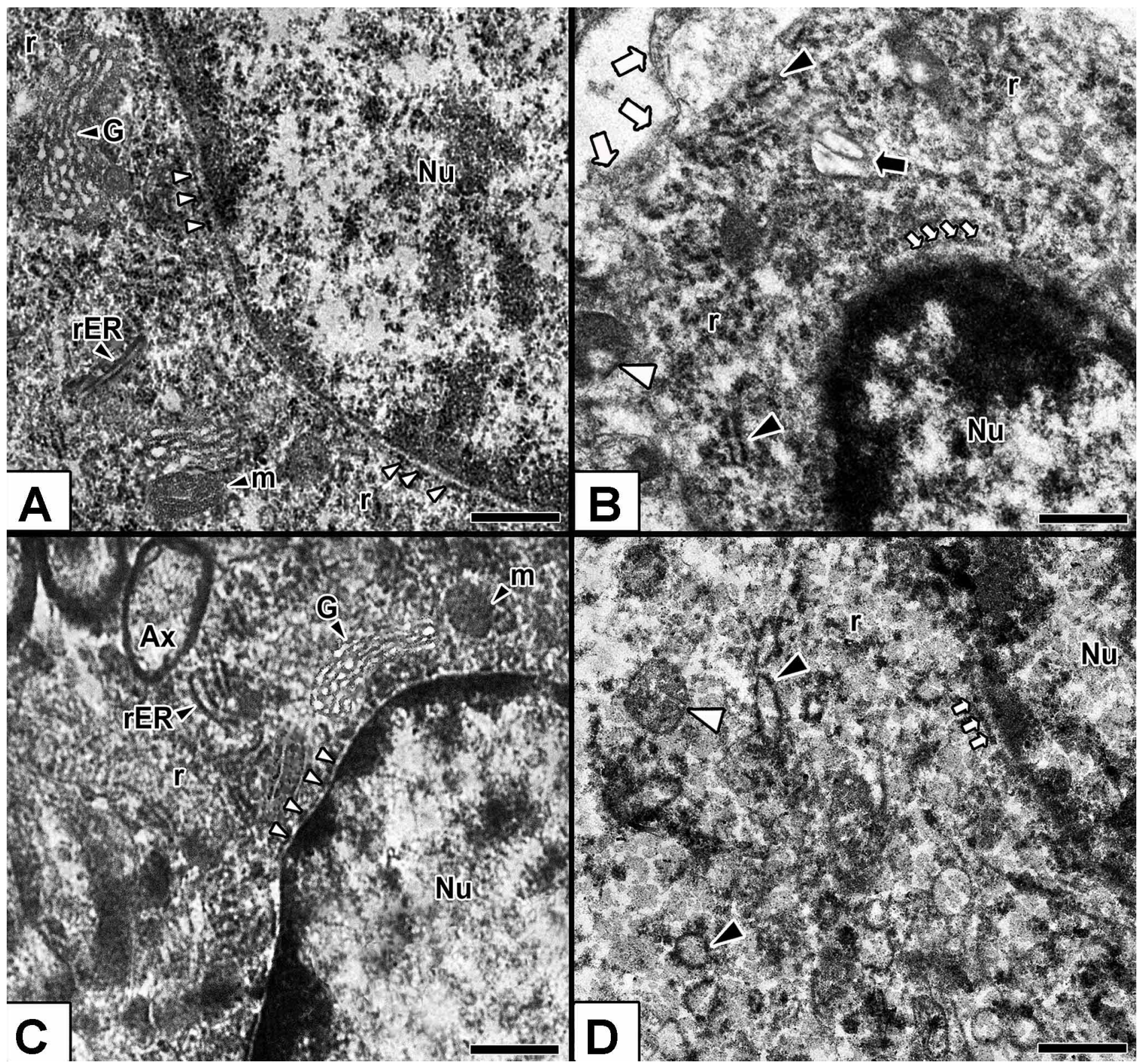

Fig. 2. Transmission electron micrographs of OLs in the cervical (2A-B) and lumbar (2C-D) enlargements of short-term control (2A, 2C) and short-term diabetic (2B, 2D) rats, at higher magnification. Nucleus $(\mathrm{Nu})$; polysomes $(\mathrm{r})$; Golgi apparatus $(\mathrm{G})$; rough endoplasmic reticulum (rER); ribosomes at the outer nuclear membrane (small white arrowheads); mitochondria (m); axon (Ax); dilated mitochondria (white arrowheads); swelling of rER (black arrowheads) and Golgi apparatus (a black arrow); swollen nuclear membranes (small white arrows); unclear boundary of cell membrane (white arrows). Scale bar $=0.5 \mu \mathrm{m}$

\section{DISCUSSION}

The OLs in cervical and lumbar enlargements among diabetic rats demonstrated similarly numerous ultrastructural changes. In short-term DM, OLs contain swollen cell organelles, which are caused by adenosine triphosphate (ATP) generation and hypertrophy of cell organelles. First, during hyperglycemia, mitochondria are activated to release ATPase inhibitory factor 1 (IF1) in both OLs and astrocytes. After IF1 binds to its receptor, the ATP synthase factor 1 (ATPSF1) gene is altered in mitochondria, causing downregulation of hexokinase and finally decreasing ATP (da-Silva et al., 2004). Astrocytes utilize stored glycogen and produce lactate (Newman, 2003). Lactate is transported from astrocytes to 


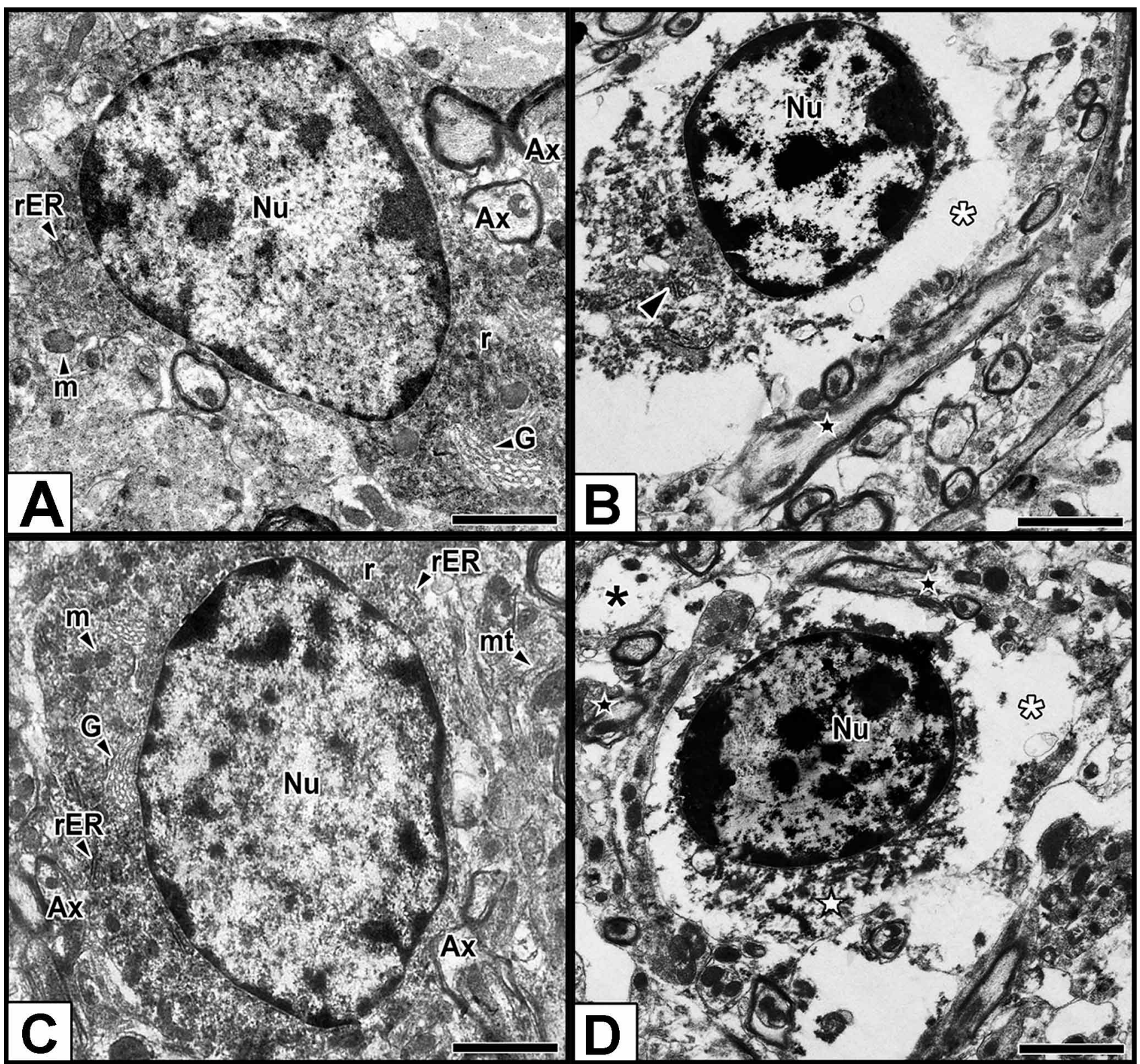

Fig. 3. Transmission electron micrographs of OLs in the cervical (3A-B) and lumbar (3C-D) enlargements of long-term control (3A, 3C) and long-term diabetic (3B, 3D) rats. Nucleus $(\mathrm{Nu})$; polysomes (r); Golgi apparatus $(\mathrm{G})$; mitochondria (m); rough endoplasmic reticulum (rER); microtubule (mt); axon (Ax); disruption of rER (a black arrowhead); electron lucent areas (white asterisks); shrunken axons (black stars); destroyed dendrite (a black asterisk); remnants of unidentified cytoplasmic organelles (a white star). Scale bar $=2 \mu \mathrm{m}$

OLs via monocarboxylate transporter (MCT) 4 and MCT1, respectively. Levels of MCT in both OLs and astrocytes increase (Tsacopoulos \& Magistretti, 1996; Canis et al., 2009). More lactate is needed in the OLs during glycolysis in DM. Lactate is utilized in pyruvate, which gives off proton ions $(\mathrm{H}+)$ to cause acidosis and induce water influx. Second, hyperglycemia increases the activity of lipoprotein lipase in the OLs to change the membrane of mitochondria, rER, and Golgi apparatus. Hyperglycemia increases the generation of hydroxyl radicals and nitric oxide (NO) in neurons, astrocytes, and OLs (Ben-Yoseph et al., 1994; Baud et al., 2004). Then, hydroxyl radicals and NO stimulate neurons and astrocytes to release an enormous level of glutamate into the extracellular matrix. During DM, the inducible isoform of nitric oxide synthase is activated to produce increased NO that stimulates glutamate synthesis inside OLs (Hampton et al., 2004; Lau \& Tymianski, 2010). Thus, the high accumulation of intracellular glutamate causes calcium ion $(\mathrm{Ca} 2+)$ diffusion into OLs. Excess $\mathrm{Ca} 2+$ increases reactive oxygen species (ROS). Therefore, the permeability of the cell membrane is altered, 


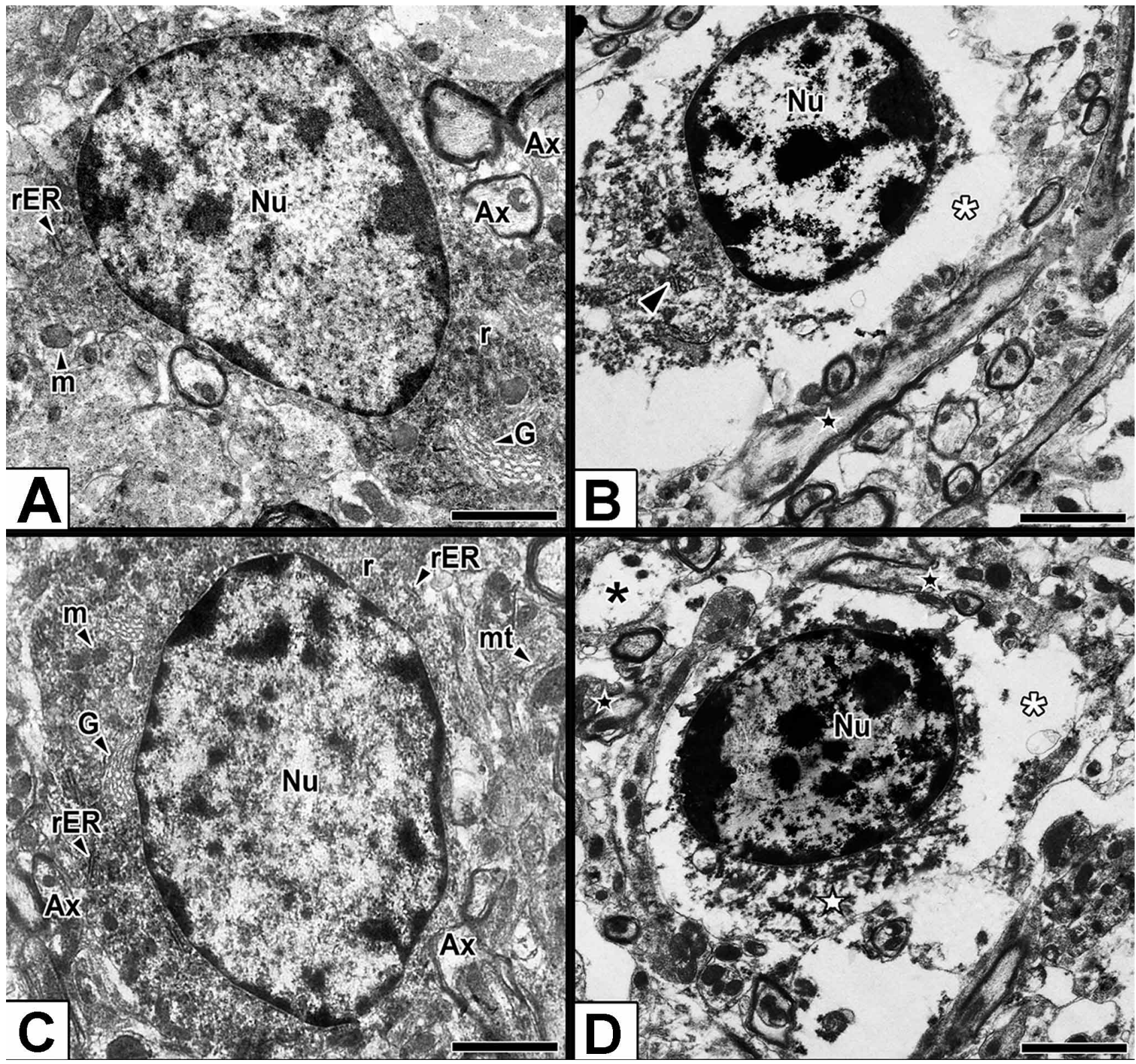

Fig. 4. Transmission electron micrographs of OLs in the cervical (4A-B) and lumbar (4C-D) enlargements of long-term control (4A, 4C) and long-term diabetic (4B, 4D) rats, at higher magnification. Nucleus $(\mathrm{Nu})$; rough endoplasmic reticulum (rER); polysomes (r); mitochondria (m); Golgi apparatus $(\mathrm{G})$; fragmented rER (black arrowheads); shrunken mitochondria with disrupted cristae (a white arrowhead); electron lucent area (a white asterisk); unidentified structure (white stars). Scale bar $=0.5 \mu \mathrm{m}$

which allows $\mathrm{H}+$ and $\mathrm{Ca} 2+$ to freely enter cellular organelles. Finally, the $\mathrm{pH}$ in these organelles becomes acidosis, that attracts water influx (Vercesi et al., 1997). Both hyperfunction of OLs and lipogenesis as well as water influx cause swelling of cell organelles and finally hypertrophy of OLs.

In long-term DM, the nuclei of OLs contained increased heterochromatin. The polyol pathway and increased ROS may be involved in the occurrence of chromatin condensation. Unused glucose in the OLs is changed into sorbitol, causing low levels of NADH. As a result, the decreased level of glutathione increases both ROS and oxidative stress, which activate cytochrome $\mathrm{C}$ in the mitochondria. Then, caspase- 3 increases and causes increased synthesis of endonuclease to cleave DNA in the nuclei. Thus, chromatin condensation occurs. Moreover, increased ROS during hyperglycemia induces protein peroxidation and protein nitrosylation leading to direct toxicity to OLs, inactive protein accumulation, and damaged DNA as condensed chromatin, which are characteristic of early apoptosis (Allen et al., 2005). 


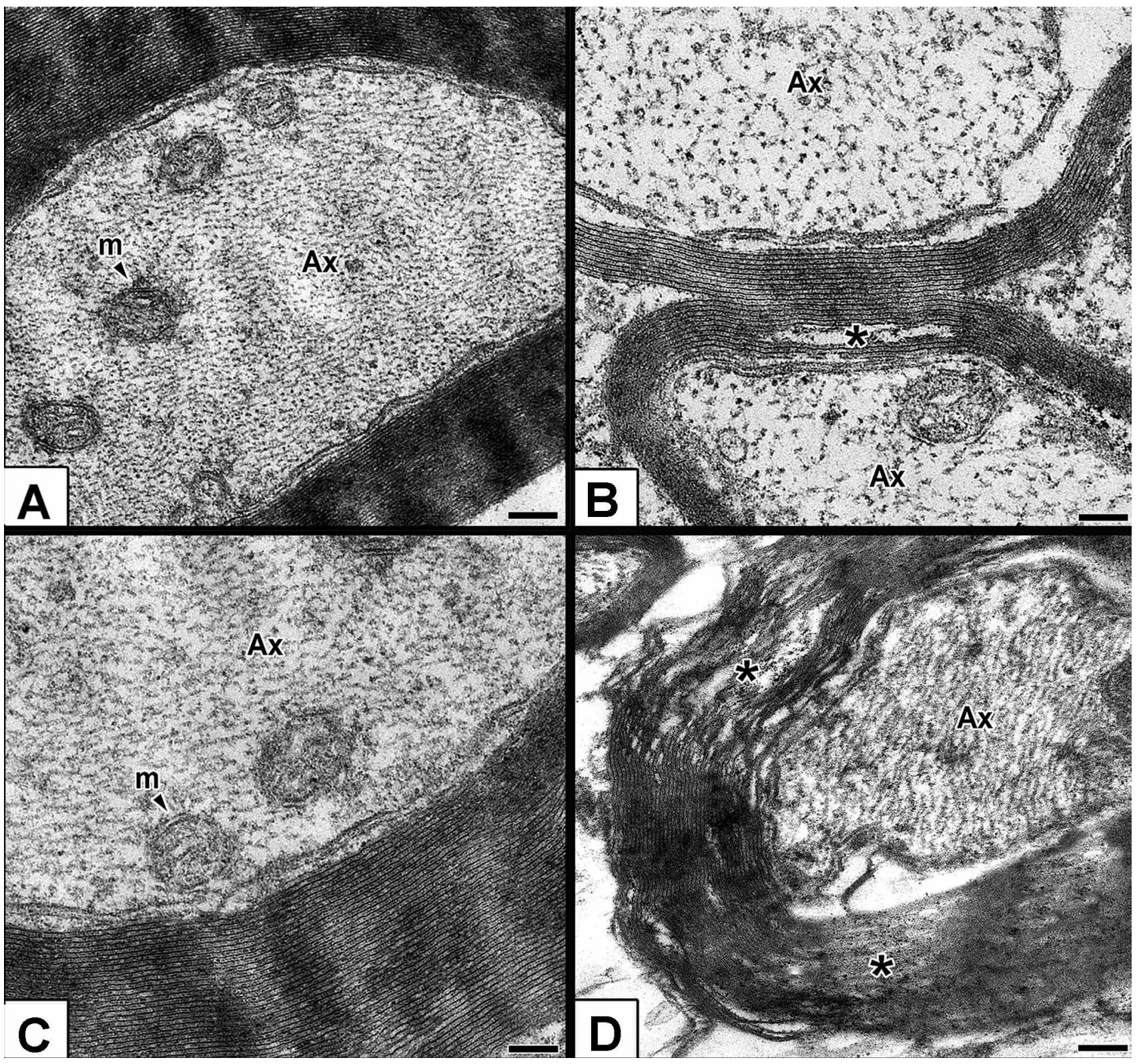

Fig. 5. Transmission electron micrographs of myelin lamellae in the spinal cord of short- (5A) and long-term (5C) controls as well as short- $(5 \mathrm{~B})$ and long-term (5D) diabetes. Axons (Ax); mitochondria (m); the splitting and loosening myelin lamellae (black asterisks). Scale bar $=0.2 \mu \mathrm{m}$.

The myelin sheaths in short- and long-term DM were split and loosened due to demyelination, resulting in increased $\mathrm{Ca} 2+$ and ROS. Excessive Ca2+ in OLs can activate two pathways. First, intracellular Ca2+ stimulates phospholipase and protease, which damage structural proteins, the cell membrane, and cell structures (Powers et al., 2005). The microtubules are the cytoskeleton of OLs, which provide the track for cellular organelle trafficking and intracellular translocation of myelin gene products, including mRNA of myelin basic protein (MBP) and proteolipid protein (PLP) for myelin formation. Therefore, the microtubules are destroyed, which affects on myelination.
Second, the excess Ca2+ increases ROS levels, causing increased fatty acid radicals and oxidative stress. As a result, MBP and PLP mRNA are degraded (Galiano et al., 2006; Kursula, 2008). Thus, there was splitting and loosening of myelin in DM.

Conclusively, it was suggested that alterations in OLs of the diabetic spinal cervical and lumbar enlargements might contribute to the slow sensory and motor conduction velocities in upper and lower limbs of the diabetic patients. This study provides benefits for further research to develop medical prevention of the severity. 
ACKNOWLEDGEMENTS. This research was supported by Siriraj Research Fund and Chalermphrakiat Grant, Faculty of Medicine Siriraj Hospital, Mahidol University, Thailand.

BAIMAI, SANI; JANTA, S.; LANLUA, P.; CHOOKLIANG, A.; NIYOMCHAN, A.; SRICHAROENVEJ, S. Oligodendrocitos alterados en la intumescencia espinal de ratas diabéticas con estreptozotocina. Int. J. Morphol., 38(6):1606-1613, 2020.

RESUMEN: En pacientes diabéticos y modelos animales se observan alteraciones de la velocidad de conducción nerviosa sensorial y motora en la médula espinal, así como vainas de mielina degeneradas. De hecho, los oligodendrocitos (OL), que son importantes células neurogliales, generan mielina en el sistema nervioso central. La intumescencia espinal, a nivel cervical y lumbar, inerva los miembros. Por lo tanto, los propósitos de este estudio fueron examinar y comparar las alteraciones ultraestructurales de los OL en la intumescencia espinal de ratas diabéticas inducidas por estreptozotocina (STZ) y controles. Se indujeron trece ratas macho Sprague-Dawley con STZ en tampón citrato y se inyectaron seis ratas de control con la misma solución tampón. Todas las ratas se sacrificaron después de la inducción a las cuatro (DM a corto plazo) y a las veinticuatro semanas (DM a largo plazo). Las ampliaciones de la columna seleccionadas se procesaron para microscopía electrónica de transmisión. Las alteraciones de OL en las intumescencias cervical y lumbar eran aparentemente las mismas. En la DM a corto plazo, los núcleos de los OL se hincharon con la acumulación de cromatina. Los orgánulos citoplasmáticos sufrieron daños moderados. En la DM a largo plazo, los OL contenían núcleos de contracción con aglutinación de heterocromatina gruesa. Se observaron mitocondrias severamente degeneradas con crestas y membranas rotas. Además, se observó un retículo endoplásmico rugoso distendido y fragmentado, y estaban presentes grandes áreas claras en el citoplasma. Además, se encontraron el aflojamiento, la división y la destrucción de las laminillas de mielina. Este estudio puede proporcionar información preliminar importante sobre la alteración de los OL en la médula espinal de los pacientes diabéticos, que podría estar involucrada en las alteraciones de las velocidades de conducción sensorial y motora en estos individuos.

PALABRAS CLAVE: Intumescencia espinal; Oligodendrocito; Mielina; Diabetes mellitus; Estreptozotocina.

\section{REFERENCES}

Allen, D. A.; Yaqoob, M. M. \& Harwood, S. M. Mechanisms of high glucoseinduced apoptosis and its relationship to diabetic complications. J. Nutr. Biochem., 16(12):705-13, 2005.

Baud, O.; Greene, A. E.; Li, J.; Wang, H.; Volpe, J. J. \& Rosenberg, P. A. Glutathione peroxidase-catalase cooperativity is required for resistance to hydrogen peroxide by mature rat oligodendrocytes. J. Neurosci., 24(7):1531-40, 2004.

Ben-Yoseph, O.; Boxer, P. A. \& Ross, B. D. Oxidative stress in the central nervous system: monitoring the metabolic response using the pentose phosphate pathway. Dev. Neurosci., 16(5-6):328-36, 1994.

Canis, M.; Maurer, M. H.; Kuschinsky, W.; Duembgen, L. \& Duelli, R. Increased densities of monocarboxylate transporter MCT1 after chronic hyperglycemia in rat brain. Brain. Res., 1257:32-9, 2009.

da-Silva, W. S.; Gómez-Puyou, A.; de Gómez-Puyou, M. T.; Moreno-Sanchez, R.; De Felice, F. G.; de Meis, L.; Oliveira, M. F. \& Galina, A. Mitochondrial bound hexokinase activity as a preventive antioxidant defense: steady-state ADP formation as a regulatory mechanism of membrane potential and reactive oxygen species generation in mitochondria. J. Biol. Chem., 279(38):39846-55, 2004.
Fauci, A. S.; Braunwald, E.; Kasper, D. L.; Hauser, S. L.; Longo, D. L.; Jameson, J. L. \& Loscalzo, J. Harrison's Manual of Medicine. $17^{\text {th }}$ ed. New York, McGraw-Hill, 2009. pp.942-6.

Fitzgerald, M. J. T.; Gruener, G. \& Mtui, E. Clinical Neuroanatomy and Neuroscience. $6^{\text {th }}$ ed. Philadelphia, Elsevier, 2011.

Galiano, M. R.; Andrieux, A.; Deloulme, J. C.; Bosc, C.; Schweitzer, A.; Job, D. \& Hallak, M. E. Myelin basic protein functions as a microtubule stabilizing protein in differentiated oligodendrocytes. J. Neurosci. Res., 84(3):534-41, 2006.

Gregersen, G. Diabetic neuropathy: influence of age, sex, metabolic control, and duration of diabetes on motor conduction velocity. Neurology, 17(10):97280, 1967.

Hampton, D. W.; Rhodes, K. E.; Zhao, C.; Franklin, R. J. M. \& Fawcett, J. W. The responses of oligodendrocyte precursor cells, astrocytes and microglia to a cortical stab injury, in the brain. Neuroscience, 127(4):813-20, 2004.

Kursula, P. Structural properties of proteins specific to the myelin sheath. Amino Acids, 34(2):175-85, 2008.

Lanlua, P.; Prommahorn, A. \& Sricharoenvej, S. Increased number of activated microglia in rat spinal cord during early stage of diabetic induction. Folia. Morhol. (Warsz.), 2019. DOI: https://www.doi.org/10.5603/FM.a2019.0136

Lau, A. \& Tymianski, M. Glutamate receptors, neurotoxicity and neurodegeneration. Pflugers. Arch., 460(2):525-42, 2010.

Newman, E. A. New roles for astrocytes: regulation of synaptic transmission.Trends Neurosci., 26(10):536-42, 2003.

Niyomchan, A.; Sricharoenvej, S; Lanlua, P. \& Baimai, S. Cerebellar synaptopathy in streptozotocin-induced diabetic rats. Int. J. Morphol., 37(1):28-35, 2019.

Olsson, Y.; Säve-Söderbergh, J.; Sourander, P. \& Angervall, L. A patho-anatomical study of the central and peripheral nervous system in diabetes of early onset and long duration. Pathol. Eur., 3(1):62-79, 1968.

Powers, S. K.; Kavazis, A. N. \& DeRuisseau, K. C. Mechanisms of disuse muscle atrophy: role of oxidative stress. Am. J. Physiol. Regul. Integr. Comp. Physiol., 288(2):R337-44, 2005.

Simons, M. \& Nave, K. A. Oligodendrocytes: myelination and axonal support. Cold Spring Harb. Perspect. Biol., 8(1):a020479, 2016.

Sricharoenvej, S.; Chookliang, A.; Lanlua, P. \& Juntararussamee, C. Effects of streptozotocin diabetes on the ultrastructure of astrocytes in the cervical enlargement of rat spinal cord. Sci. Res. Essays, 10(22):640-8, 2015.

Tehrani, K. H. N. A study of nerve conduction velocity in diabetic patients and its relationship with tendon reflexes (T-reflex). Open Access Maced. J. Med. Sci., 6(6):1072-6, 2018.

Terada, M.; Yasuda, H.; Kikkawa, R.; Koyama, N.; Yokata, T. \& Shigeta, Y. Electrophysiological study of dorsal column function in streptozocin-induced diabetic rats: comparison with 2,5-hexanedione intoxication. J. Neurol., Sci., 115(1):58-66, 1993.

Tsacopoulos, M. \& Magistretti, P. J. Metabolic coupling between glia and neurons. J. Neurosci., 16(3):877-85, 1996.

Vercesi, A. E.; Kowaltowski, A. J.; Grijalba, M. T.; Meinicke, A. R. \& Castilho, R. F. The role of reactive oxygen species in mitochondrial permeability transition. Biosci. Rep., 17(1):43-52, 1997.

Williamson, R. T. Changes in the spinal cord in diabetes mellitus. Br. Med. J., 1(2246):122-3, 1904

Yadav, N.; Shete, A.; Yahav, P.; Yadav, N. \& Khan, S. T. Study of nerve conduction velocity in type II diabetes mellitus. N. J. I. R. M., 64(4):36-43, 2015.

\section{Corresponding author: \\ Sirinush Sricharoenvej, Ph.D. \\ Department of Anatomy \\ Faculty of Medicine Siriraj Hospital \\ Mahidol University \\ Bangkok 10700 \\ THAILAND}

Email: sirinush.sri@mahidol.ac.th

Received: $10-07-2020$

Accepted: 15-08-2020 